\title{
The impact of covid-19 on the implementation of learning in the digital era 4.0
}

\author{
Muhammad Alwan ${ }^{1}$ * \\ *Department of Education and Teacher, STAI Darul Kamal NW Kembang Kerang NTB, \\ Indonesia
}

\section{Article Info}

Received 10 Nop, 2020

Revised 15 Dec, 2020

Accepted 20 Jan, 2021

Available online,

$28 \mathrm{Feb}, 2021$

Keywords:

Digital, Implementation, Learning, Skill

\begin{abstract}
A b stract
This article discusses how the impact of Covid-19 on the implementation of learning in the digital era 4.0. On the other hand, this research also explores the potential emergence of the skills of students in the digital-based learning process. For this purpose, the research was conducted using a literature review (library research). The theme of learning associated with Covid-19 has recently been interesting to study through research. Several research results found that e-learning based learning with application variants during the pandemic was insignificant. Contradictory to the nature of digital learning media which always attracts the attention of students in general. This is relevant to the development period of children who are interested in digital visual media. On the other hand, life and career skills in the 21 st century began to be tried during the Covid-19 learning period, such as flexibility and adaptability in the learning process during the Covid-19 period, which led to a variety of creativity and independence among students.
\end{abstract}

${ }^{1}$ Correspondence to the author, Prodi Pendidikan Guru Madrasah Ibtidaiyah, STAI Darul Kamal NW Kembang Kerang, NTB, Indonesia, email address: muhammadalwan402@gmail.com https://scholar.google.com/citations?hl=id\&user=UJnqHy0AAAAJ 


\title{
Dampak covid-19 terhadap implementasi pembelajaran di era digital 4.0
}

\begin{abstract}
A b strak
Artikel ini membahas tentang bagaimana dampak Covid-19 terhadap implementasi pembelajaran di era digital 4.0. Di sisi lain, research ini juga mengeksplorasi potensi munculnya skill-skill peserta didik dalam proses pembelajaran berbasis digital. Untuk tujuan ini maka penelitian dilakukan menggunakan kajian literature (library research). Tema tentang pembelajaran dikaitkan dengan Covid-19 belakangan menarik untuk dikaji melalui penelitian. Beberapa hasil penelitian ditemukan bahwa pembelajaran berbasis e-learning dengan varian aplikasi di masa pandemi tidak signifikan. Kontradiktif dengan sifat media pembelajaran digital yang salalu menarik perhartian siswa pada umumnya. Ini relevan dengan masa perkembangan anak-anak yang tertarik dengan media visual digital. Disisi lain, keterampilan-keterampilan hidup dan berkarir abad 21 mulai dicoba pada pembelajaran masa Covid-19 seperti fleksibilitas dan adaptabilitas pada proses pembelajaran masa Covid-19 sehingga memunculkan berbagai kreatifitas dan kemandirian di kalangan siswa.
\end{abstract}

Kata Kunci: Digital, Implementasi, Ketrampilan, Pembelajaran

\section{Pendahuluan}

Pada tahun 2019 muncul kasus phneumonia yang misterius tepatnya pada Desember, kasus ini pertama kali dilaporkan terjadi di Wuhan Provinsi Hubei China. Pada awal tahun 2020 dunia dikejutkan dengan wabah virus corona (Covid-19) yang menginfeksi hamper seluruh Negara di dunia. Sehingga pada Januari 2020 WHO menetapkan bahwa Covid-19 dinyatakan masuk ke dalam darurat global . hal ini merupakan fenomena yang luar biasa yang terjadi di muka bumi dan memiliki skala yang sangat besar karena merenggut jutaan ribu nyawa manusia. Selain itu, dengan munculnya covid-19 berdampak pada penundaan even-even besar dunia misalnya pertandingan-pertandingan olahraga dan sebagainya.

Coronavirus merupakan virus RNA strain tunggal positif, berkapsul dan tidak bersigmen. Corona virus tergolong ordo Nidovirales, keluarga Corona viridae. Struktur corona virus membentuk struktur seperti kubus dengan protein $\mathrm{S}$ berlokasi di permukaan virus. Protein $\mathrm{S}$ atau spike protein merupakan salah satu protein antigen utama virus dan merupakan struktur utama penulisan gen. 
Protein S ini berperan dalam penempelan dan masuknya virus ke dalam sel host (interaksi protein S dengan reseptornya di sel inang) (Yuliana, 2020)

Covid-19 saat ini merupakan bencana non alam yang telah menyebar ke seluruh dunia. Wabah Covid-19 merupakan krisis kesehatan yang pertama dan terutama di dunia (Agus, 2020). Virus corona berdampak pada munculnya kebijakan pada setiap Negara untuk menutup aktifitas sekolah-sekolah, perguruan tinggi, dan kampus untuk sementara waktu. Covid-19 tidak hanya hanya mempengaruhi ekonomi dan politik di Negara terdampak namun juga pada bidang pendidikan secara menyeluruh hal tersebut sejalan dengan pernyataan organisasi dunia melalui World Health Organization (WHO) menangkap bahwa pendidikan menjadi salah satu sektor yang begitu terdampak oleh covid-19. Menurut data United Nations Educational, Scientific and Culture Organization (UNESCO) terdapat 102 negara telah menerapkan penutupan sekolah secara nasional. Hal ini berdampak pada 849,4 juta anak dan remaja tidak dapat melaksanakan kegiatan belajar di sekolah dan kampus selama waktu yang ditentukan setiap Negara, penentuan waktu dilaksanakan didasarkan pada perkembangan kasus covid-19 pada setiap Negara (Republika, 2020).

Social Distancing dan Physical distancing merupakan salah satu kebijakan yang diterapkan untuk dapat terhindar dan tercegah dari terkena covid-19, dimana masyarakat dihimbau untuk tetap berada "di rumah saja" untuk menjalankan segala bentuk aktifitas termasuk ibadah. Pemerintah Indonesia sendiri belum mengambil keputusan terkait dengan lockdown, dan lebih mengedapankan social distancing (mengurangi kerumunan massa), dan self carantina (karantina/isolasi diri) (Debora, 2020). Namun banyak daerah-daerah menerapkan kebijakan berbeda. Presiden Joko Pemerintah Indonesia menekankan bahwa kebijakan lockdown di setiap Negara berbeda karena setiap Negara memiliki karakter, budaya, dan kedisiplinan, dan keputusan yang berbeda sehingga Indonesia masih menerapkan physical distancing. Adapun daerah-daerah yang memutuskan untuk membatasi aktivitas di wilayahnya terutama untuk kegiatan wisata, sekolah-sekolah, dan acara-acara yang menghadirkan banyak orang yaitu Solo, Tegal, Papua, dan lain sebagainya.

Di Indonesia melalui Menteri Pendidikan dan Kebudayaan menerbitkan surat edaran untuk mengatur pelaksanaan pendidikan masa darurat virus corona dengan menerapkan konsep "Belajar dari Rumah", "Work From Home", dan "Ibadah dari Rumah" yang dinilai sebagai upaya yang tepat dalam memutus mata rantai penyebaran covid-19 di lingkungan sekolah. Sehingga kebijakan tersebut maka muncul inovasi dalam proses belajar mengajar dengan menerapkan pembelajaran jarak jauh (PJJ) yaitu dengan pembelajaran berbasis online. Akibat pandemic covid-19 semua jenjang pendidikan memperolah dampak negative yang luar biasa dimana semua siswa sampai mahasiswa 
dipaksa untuk belajar dari rumah karena pembelajaran tatap muka ditiadakan untuk mencegah penularan covid-19. Kondisi ini membuat siswa dan mahasiswa harus sedapatmungkin dapat beradaptasi dengan perubahan ini, karena ini merupakan hal yang tidak biasa dan hal yang baru bagi kalangan siswa pada tingkat dasar hingga menengah atas. Karena kondisi ini tidak biasa dilakukan tentu akan muncul rasa berat pada setiap diri siswa karena tidak terbiasa dengan pola pembelajaran baru yaitu pembelajaran online. Apalagi guru dan dosen masih banyak yang belum mahir melakukan pembelajaran dengan menggunakan teknologi internet atau media-media online lainya seperti social media, moodle, dan lain sebagainya.

Munculnya pembelajaran online sebagai upaya alternative untuk mengganti pembelajaran tatap muka merupakan hal yang baru namun tidak asing karena pada beberapa tahun sebelumnya pemerintah melalui kementerian pendidikan telah mengeluarkan peraturan menteri (Permen) tentang penyelenggaraan pendidikan jarak jauh yang mengemukakan PJJ adalah pendidikan yang peserta didiknya terpisah dari pendidik dan pembelajarannya menggunakan berbagai sumber belajar melalui penerapan prinsip-prinsip teknologi pendidikan/ pembelajaran. Pendidikan Jarak Jauh jenjang pendidikan dasar, menengah, hingga pendidikan tinggi bertujuan meningkatkan perluasan dan pemerataan akses pendidikan, serta meningkatkan mutu dan relevansi pendidikan dasar dan menengah. PJJ mempunyai karakteristik terbuka, belajar mandiri, belajar tuntas, menggunakan teknologi informasi dan komunikasi pendidikan, dan/atau menggunakan teknologi pendidikan lainnya (Permendikbud nomor 119 tahun 2014).

\section{Metode}

Metode penelitian ini menggunakan penelitian kepustakaan (Library Research). Penelitian kepustakaan merupakan suatu penelitian yang digunakan dalam mengumpulkan sejumlah buku-buku, majalah, kisah-kisah, sejarah, berita dan sebagainya. Penelitian kepustakaan merupakan kajian teoritis, referensi serta literature ilmiah lainnya yang berkaitan dengan budaya, nilai, dan norma yang berkembang pada situasi social yang diteliti (Sugiono, 2012). Data dikumpulkan melalui teknik dokumentasi yang terkait dengan persoalan yang diteliti. Kemudian, analisis data dilakukan dengan menggunakan metode analisis kontent (content analysis) yang diawali dengan prosedur reduksi data, display dan menarik interpretasi (kesimpulan). 


\section{Hasil dan Pembahasan}

\subsection{Pendidikan Revolusi Industri Era 4.0}

Adalah Klaus Schwab, Ekonom terkenal dunia asal Jerman, Pendiri dan Ketua Eksekutif World Economic Forum (WEF) yang mengenalkan konsep Revolusi Industri 4.0. Dalam bukunya yang berjudul "The Fourth Industrial Revolution", Schawab menjlaskan bahwa revolusi industry 4.0 telah mengubah cara hidup, bekerja, dan cara berhubungan dengan sesama secara fundamental (Delipter Lase. 2019). Berbeda dengan revolusi industri sebelumnya, revolusi industri generasi ke-4 ini memiliki skala, ruang lingkup dan kompleksitas yang lebih luas. Kemajuan teknologi baru yang mengintegrasikan dunia fisik, digital dan biologis telah mempengaruhi semua disiplin ilmu, ekonomi, industri dan pemerintah. Bidang-bidang yang mengalami terobosoan berkat kemajuan teknologi baru diantaranya (1) robot kecerdasan buatan (artificial intelligence robotic), (2) teknologi nano, (3) bioteknologi, dan (4) teknologi komputer kuantum, (5) blockchain (seperti bitcoin), (6) teknologi berbasis internet, dan (7) printer $3 \mathrm{D}$.

Revolusi industri 4.0 telah mengubah sistem pembelajaran yang ada saat ini. Pembelajaran seyogyanya merupakan suatu interaksi antara guru dengan siswa kini menjadi tergantikan dengan munculnya berbagai teknologi yang muncul yang mendukung pembelajaran. Pembelajaran abad 21 sejalan dengan pendidikan 4.0 mengdepankan kepada skill sebagaimana diungkapkan dalam sebuah artikel "pendidikan 4.0 adalah program untuk mendukung terwujudnya pendidikan cerdas melalui peningkatan dan pemerataan kualitas pendidikan, perluasan akses, dan relevansi memanfaatkan teknolog dalam mewujudkan pendidikan kelas dunia untuk menghasilkan peserta didik yang memiliki setidaknya 4 keterampilan abad 21 yaitu kolaborasi, komunikasi, berfikir kritis, dan kreatif. Hal tersebut mengacu pada standar kompetensi global dalam mempersiapkan generasi muda memasuki realitas kerja global dan kehidupan abad 21 (DUGI, 2019).

Tantangan SDM Pembangunan Indonesia pada era revolusi industri 4.0 yaitu relevansi pendidikan dan pekerjaan perlu disesuaikan dengan perkembangan era dan iptek dengan tetap memberikan perhatian kepada aspek humanities. Selain itu agar lulusan bisa kompetitif maka kurikulum perlu orientasi baru lebih-lebih pada masa covid-19 ini sebab adanya era revolus industri 4.0 tidak hanya cukup dengan keterampilan membaca, menulis, dan matematika sebagai modal dasar untuk berkiprah di masyarakat. Tetapi generasi yang harus disiapkan dalam menghadapi era digital ini adalah sumber daya manusia yang memiliki jiwa kompetitif yang mempunyai kemampuan untuk membaca, analisis, dan menggunakan informasi (big data) di dunia digital yang 
disebut dengan istilah literasi data. Selanjutnya kemampuan literasi teknologi yaitu yang menyangkut pemahaman dan penguasaan cara kerja mesin, aplikasi teknologi yang meliputi coding, artificial intelegence, dan engineering principles. Kemudian literasi manusia yang meliputi humanities, komunikasi, dan desain (Intan, 2018). Dalam kehidupan siswa harus dibekali kemampuan leadership (kepemimpinan) dan kemampuan bekerja dalam tim (team work) serta memiliki kematangan dalam budaya karena setiap orang tentu memiliki latar belakang budaya yang berbeda satu dengan yang lainnya, sehingga berawal dari keragaman tersebut dapat menjadi peluang dalam membangun jaringann antara yang satu dengan yang lain baik hubungan dengan dalam negeri maupun network dengan luar negeri. Kemudian setiap orang pada dasarnya harus memiliki jiwa enterpreneurship yaitu jiwa wirasuaha, hal ini mesti ada karena ini mengubah mindset lulusan agar mampu menicptakan lapangan kerja baru, dan tidak berorientasi kepada pemikiran bahwa ketika lulus akan menjadi ASN, menjadi dokter, dan lain sebagainya.

Berikut ini beberapa keterampilan hidup dan berkarir abad 21 yang relevan dengan masa Covid-19 yaitu sebagai berikut:

Tabel 1. Keterampilan hidup dan berkarir Abad 21

Diadopsi dari Trilling dan Fadel (2009) (dalam Nusantara, 2018)

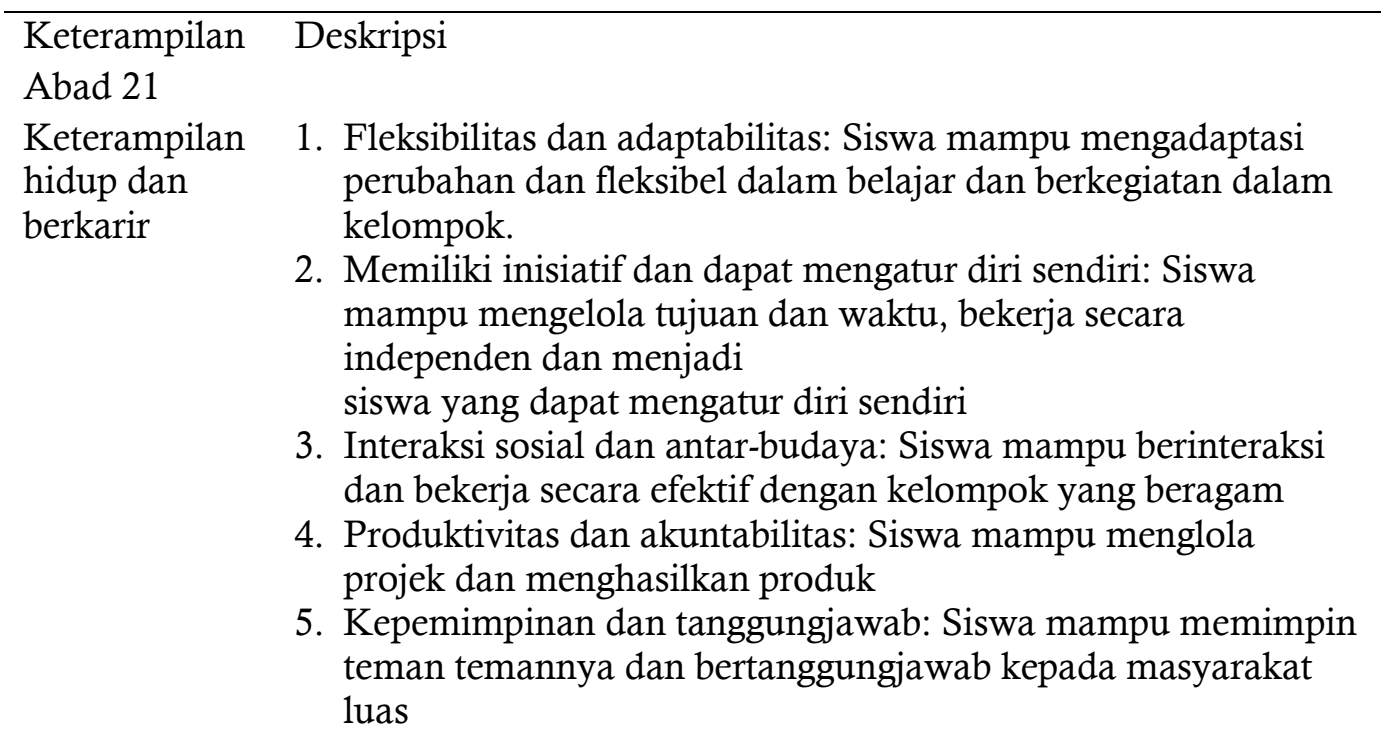

Selanjutnya yaitu kemampuan Learning and Innovation skills (keterampilan belajar dan berinovasi) yang meliputi (1) berfikir kritis dan mengatasi masalah (Critical Thinking And Problem Solving), (2) komunikasi dan berkolaborasi (Communication and Collaboration), (3) kreatifitas dan inovasi (Creativity and 
Innovation), untuk memperoleh penjelasan detail sebagaimana disajikan dalam tabel sebagai berikut:

Tabel 2. Keterampilan Belajar dan berinovasi

Diadopsi dari Trilling dan Fadel (2009) (dalam Nusantara, 2018)

\begin{tabular}{ll}
\hline Keterampilan Abad 21 & Deskripsi \\
Keterampilan Belajar & $\begin{array}{l}\text { 1. } \\
\text { dan Berpikin kritis dan mengatasi masalah: siswa } \\
\text { mampu mengunakan berbagai alasan (reason) } \\
\text { seperti induktif atau deduktif untuk berbagai } \\
\text { situasi; menggunaan cara berpikir sistem; }\end{array}$ \\
& membuat keputusan dan mengatasi masalah \\
2. & Komunikasi dan kolaborasi: siswa mampu \\
& berkomunikasi dengan jelas dan melakukan \\
& kolaborasi dengan anggota kelompok lainnya \\
& 3. Kreativitas dan inovasi: siswa mampu berpikir \\
& kreatif, bekerja secara kreatif dan menciptakan \\
& inovasi baru
\end{tabular}

Information media and technology skills (keterampilan teknologi dan media informasi) meliputi (a) literasi informasi (information literacy), (b) literasi media (media literacy), dan (c) literasi ICT(information and Communication Technology).

Tabel 3. Tecnologi dan media informasi

Diadopsi dari Trilling dan Fadel (2009) (dalam Nusantra, 2018)

\begin{tabular}{ll}
\hline Keterampilan Abad 21 & Deskripsi \\
Keterampilan teknologi dan & 1. Literasi informasi: siswa mampu mengakses \\
media informasi & informasi secara efektif (sumber nformasi) dan \\
& efisien (waktunya); mengevaluasi informasi \\
& yang akan digunakan secara kritis dan \\
& kompeten; mengunakan dan mengelola \\
& informasi secara akurat dan efektf untuk \\
& mengatasi masalah. \\
2. $\begin{array}{l}\text { Literasi media: siswa mampu memilih dan } \\
\text { mengembangkan media yang digunakan untuk } \\
\text { berkomunikasi. }\end{array}$ & 3. $\begin{array}{l}\text { Literasi ICT: siswa mampu menganalisis } \\
\text { media informasi; dan menciptakan media yang } \\
\text { sesuai untuk melakukan komunikasi. }\end{array}$
\end{tabular}


Kemampuan-kemampuan di atas dapat diwujudkan melalui beberapa cara mengajar agar tujuan di atas dapat tercapai dengan baik, yaitu (1) studi tematik berbagai disiplin ilmu, hubungan dengan dunia nyata project based-leaming, (2) melalui general education, ekstrakurikuler, dan (3) Magang/kerja praktek.

\subsection{Pembelajaran pada masa pandemi Covid-19}

Luthra \& Mackenzi (2020) menyebut ada empat cara covid mengubah cara mendidik generasi masa depan. Pertama, bahwa proses pendidikan di seluruh dunia semakin saling terhubung. Kedua, pendefinisian ulang peran pendidik. Ketiga, mengajarkan pentingnya keterampilan hidup di masa yang akan datang. Dan keempat, membuka lebih luas peran teknologi dalam menunjang pendidikan (Anggi, 2020). Hal tersebut senada dengan konsep revolusi era digital 4.0 bahwa yang cenderung menekankan kepada saling keterhubungan kemudian kolaboratif yang menjangkau peserta didik dan pendidik serta praktisi pendidikan dimanapun dan kapanpun. Sehingga muncul pergeseran paradigma peran pendidik atau seorang guru dalam proses pembelajaran tidak lagi menjadi sumber ilmu. Selain itu, Tm dan El Azar (2020) menyatakan "pandemic covid19 menyebabkan tiga perubahan mendasar di dalam pendidikan global. Yang pertama, mengubah cara jutaan orang dididik. Kedua, solusi baru untuk pendidikan yang dapat membawa inovasi yang sangat dibutuhkan. Ketiga, adanya kesenjangan digital menyebabkan pergeseran baru dalam pendekatan pendidikan dan dapat memperluas kesenjangan".

Apa yang disampaikan kedua pendapat di atas menunjukan betapa covid19 telah membawa percepatan tranformasi pendidikan yang awalnya sangat lambat, namun dengan adanya wabah covid-19 mau tidak mau bahwa transformasi pendidikan harus dilakukan seluruh dunia secara spontan mengubah pola pembelajaran konvensional berbasis tatap muka menjadi pembelajaran jarak jauh (PJJ) yang sangat mengandalkan teknologi. Di Indonesia sendiri pola pembelajaran daring dikuatkan dengan surat edaran Menteri Pendidikan Dan Kebudayaan Republik Indonesia Nomor : 36962/MPK.A/HK/2020. Prihal Pembelajaran secara Daring dan Bekerja dari Rumah dalam Rangka Pencegahan Penyebaran Corona Virus Disease (COVID19). Kemudian terdapat juga surat Edaran Kemendikbud No 4 Tahun 2020 mengenai pelaksanaan pendidikan dalam masa darurat Coronavirus Disease (Covid-19) yang berisi tiga poin penting terkait pembelajaran daring yaitu (1) pembelajaran daring/jarak jauh untuk memberi pengalaman belajar yang bermakna, tanpa terbebani tuntutan menuntaskan seluruh capain kurikulum untuk kenaikan kelas maupun kelulusan. (2) dapat difokuskan pada pendidikan 
kecakapan hidup, antara lain mengenai pandemic Covid-19. (3) aktifitas dan tugas pembelajaran dapat bervariasi antar siswa, sesuai minat dan kondisi masing-masing, termasuk mempertimbangkan kesenjangan akses/fasilitas belajar di rumah. Namun kebijakan tersebut menuai permasalahan karena kondisi masyarakat yang beragam sehingga aplikasi pembelajaran online terhambat oleh kondisi masyarakat yang tidak semua memiliki akses internet, kemudian tidak semua siswa memiliki sarana untuk melakukan kegiatan pembelajaran online terebut misalnya siswa dan guru tidak memilki fasilitas Handphone atau laptop sebagai media akses karena baik siswa maupun guru harus saling terkoneksi internet barulah kemudian dapat terjadi interaksi antara guru dan siswa. Sehingga kebijakan tersebut tergantung dari dukungan kebijakan pemrintah dalam beberapa hal Pertama yaitu, pemerintah pusat mesti menjamin dengan menyediakan koneksi internet yang lancar dan stabil, subsidi kuota, bantuan perangkat digital, dan peningkatan kapasitas digital juga meminimalisir ketimpangan akses di berbagai wilayah. Namun pada akhirnya untuk mengatasi permasalahan tersebut pemerintah membolehkan anggaran Dana BOS untuk mendukung pelaksanaan pembelajaran daring, kemudian pemerintah juga bekerjasama dengan TVRI untuk menampilkan program edukasi yang menyajikan materi mulai dari tingkat sekolah dasar sampa tingkat sekolah menengah atas yang ditayangkan secara berjadwal.

Kedua, kapasitas sekolah bergantung pada capital yang dimiliki oleh sekolah seperti infrastruktur yang mendukung operasional pembelajaran secara daring antara lain koneksi internet, kuota, laptop, dan penguasaan teknologi. Latar belakang siswa secara social ekonomi juga dapat mempengaruhi apakah kegiatan belajar jarak jauh melalui beragam perangkat daring misalnya zoom, google meet, google classroom, whatsApp, dan lain sebagainya. Ini merupakan kondisi yang tidak dapat kita pungkiri bahwa keadaan di desa dan pelosok dengan perkotaan jauh berbeda. Ketika sekolah negeri di perkotaan yang notabene memiliki tingkat ekonomi menengah ke atas tentu tidak akan mengalami kesulitan dalam menjalani pembelajaran karena tidak ada masalah terhadap internet dan perangkat teknologi. Kondisi ini akan berbanding terbalik manakala dihadapkan pada sekolah negeri atau swasta di daerah pedesaan yang input siswanya kebanyakan dari kalangan miskin tentu akan mengalami kendala dan keterbatasan dalam jaringan internet dan perangkat teknologi.

Ketiga, kreativitas guru dalam mendesain pembelajaran daring bagi siswa memegang peranan pentng. Untuk memastikan pembelajaran menyenangkan, penuh makna, membangkitkan kreativitas, daya kritis, dan mampu membuat mandiri tentu bukan perara mudah. Apalagi guru tidak lagi secara langsung bertatap muka dengan siswa. kejelian guru dalam membuat desain dan metode yang mampu memikat siswa untuk terus bersemnagat belajar menjadi hal yang 
patut diperhatikan. Karena jika hanya memberi beban tugas kepada siswa tentu membuat siswa menjadi jenuh. Undang-Undang No.14 Tahun 2015 telah menegaskan bahwa pendidik yang prfesional adalah pendidik yang memiliki empat kompetensi dasar guru professional, yaitu kompetensi pedagogic, kompetensi kepribadian, kompetensi profesionalitas, dan kompetensi social. Kompetensi pedagogic dalam hal ini adalah kemampuan mengelola pembelajaran peserta didik. Sedangkan kompetensi kepribadian adalah kemampuan kpribadian yang mantap, berkahlak mulia, arif, dan berwibawa serta menjadi teladan peserta didik. Kompetensi professional yang dimaksud dalam undang-undang tersebut adalah kemampuan penguasaan materi pelajaran secara luas dan mendalam. Sedangkan kompetensi social adalah kemampuan guru untuk berkomunikasi dan berinteraksi secara efektif dan efisien dengan peserta didik, sesame guru, orang tua wali, dan masyarakat sekitar. Keterampilan merancang pembelajaran adalah salah satu kemampuan pembentuk kompetensi pedagogis seorang pendidik, yaitu mampu merancang pembelajaran untuk mencapai pembelajaran (Putrawangsa, 2018).

Berdasarkan undang-undang maka tugas seorang guru adalah bagaimana merancang pembelajaran agar menjadi menarik dan interaktif teutama dalam masa pandemi ini, maka guru dapat merancang pembelajaran berbasis web. Misalnya dengan mebuat multimedia pembelajaran sebagaimana diungkapkan oleh Conrad dan Voris bahwa dari sudut pandang pedagogis multimedia merupakan strategi pembelajaran yang terkait dengan konstruktivis, kognitivis, dan paradigm pembelajaran kolaboratif atau kombinasi dari beberapa strategi (Conrad, et all, 2002). Dari sudut pandang isi yaitu implementasi berbasis komuter dari suatu objek tertentu yang biasanya sesuai dengan kurikulum. Atas dasar tersebut maka pembelajaran melalui e-learning merupakan pembelajaran dengan integrasi dari konten (isi), teknologi, dan pedagogi yang mejadi kesatuan system yang saling mendukung pembelajaran. Adapun unsur-unsur yang harus ada dalam pembelajaran berbasis online agar dapat menarik adalah (1) menggunakan teknologi web, (2) mengajarkan konten sesuai dengan tujuan pembelajaran, (3) rancangan berdasarkan strategi pembelajaran dan prosedur pedagogis, (4) berisi elemen yang dapat digunakan kembali. Berkaitan dengan hal tersebut maka fitur-fitur yang diperlukan pada layanan e-learning yaitu (1) informasi pelajaran, catatan pengumuman dan jadwal, (2) peta kurikulum, (3) bahan ajar seperti slide handout, animasi, audio video, (4) komunikasi melalui email dan forum, (5) penilaian formatif dan sumatif, (6) alat manajemen siswa (records, statistics, student tracking), (7) link ke website terkait secara internal maupun eksternal yang bermanfaat seperti perpustakaan, online database, dan jurnal (Tambunan, 2013). 
Keempat, partisipasi orangtua menjadi sangat penting untuk menyukseskan pembelajaran daring.Situasi dilematis kemudian terjadi ketika orangtua tidak dapat hadir mendampingi anak karena masih harus bekerja. Mereka adalah orang-orang yang tidak memiliki kemewahan untuk bekerja dari rumah. Para petugas kesehatan, pekerja informal, buruh pabrik, peternak, nelayan, an petani misalnya harus tetap bekerja. Sementara mereka tidak memiliki orang lain yang dapat membantu mendapingi anak. Para orangtua yang memiliki kesempatan bekerja dari rumah tetapi tetap memprioritaskan pekerjaan kantor juga tidak dapat membantu anak-anak belajar secara optimal. Khusus bagi anak-anak di usia dini ini tentu menjadi perkara. Jika kedua orangtua bekerja dan mereka tidak memiliki asisten rumah tangga misalnya, mereka harus mampu membagi peran untuk mengasuh anak. Jika tidak dapat disikapi secara bijak, lagi-lagi isu kesehatan mental menjadi bagian yang perlu diantisipasi.

Djoko Saryono dalam webinar internasional "inovasi pembelajaran efektif di tengah pandemic-infodemi covid 19" mengemukakan bahwa semua sektor kehidupan terdampak oleh pandemic-infodemi covid-19, semua sendi kebudayaan/peradaban terdampak pandemic-infodemi covid-19, dan semua sendi pendidikan nasional terdampak pandemic-infodemi covid-19. Kondisi ini tidak bisa lantas kita melakukan konfrontasi tetapi yang mesti dilakukan adalah beradaptasi dengan kondisi ini dan pendidikan melakukan adaptasi secara gesit, tangkas, dan lentur. Di sinilah diperlukan agilitas, pola piker agilitas, dan inovasi yang gesit dan lentur (Djoko, 2020). Konsekuensi adaptasi dalam proses pendidikan memunculkan beberapa hal sebagaimana gambar di bawah ini:

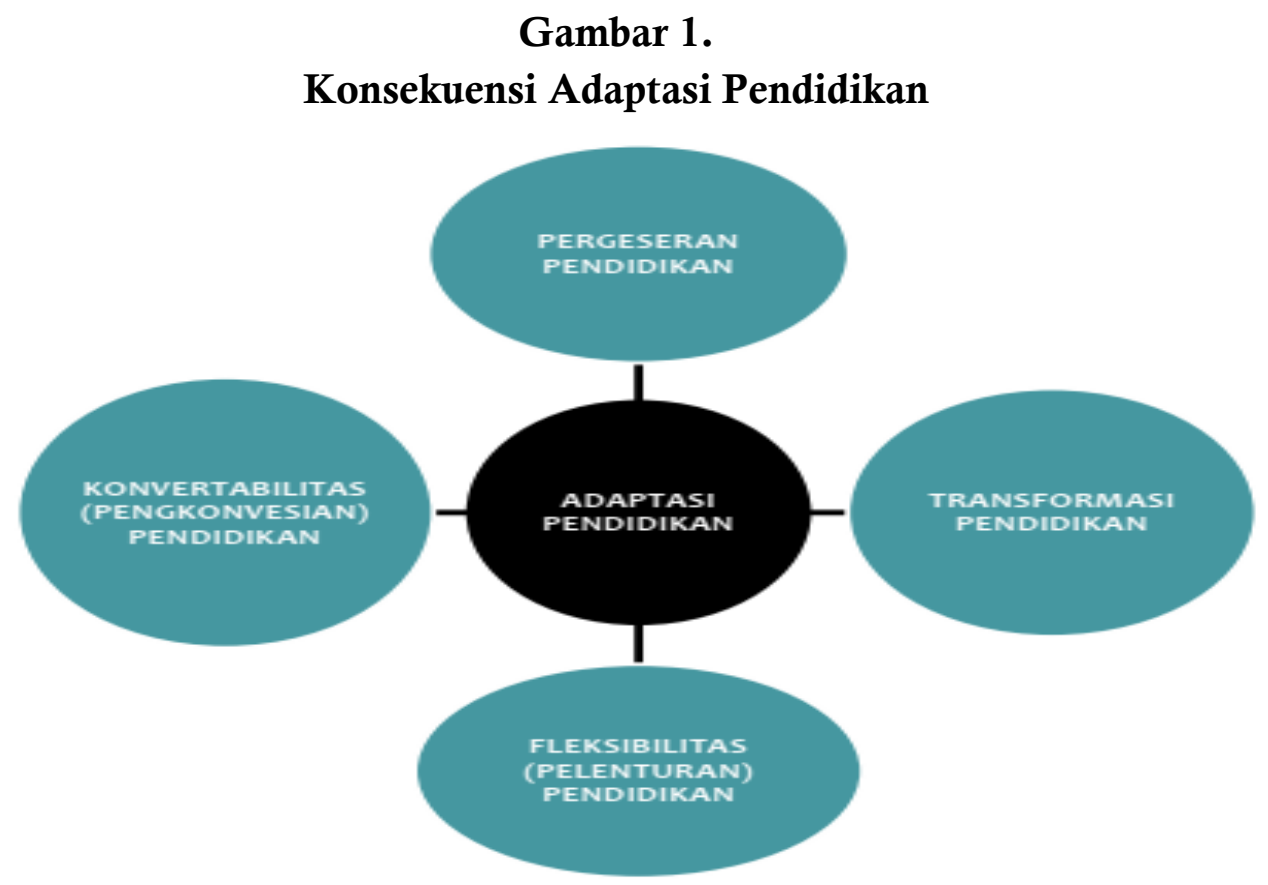


Berdasarkan gambar di atas, maka konsekuensi dari adaptasi memunculkan empat hal yaitu Transformasi pendidikan, Pergeseran Pendidikan, Konvertabilitas (pengkonversian) pendidikan Tranformasi pendidikan, dan Fleksibilitas (Pelenturan) Pendidikan. Tranformasi pendidikan merupakan perubahan cara belajar siswa dan pendidik yang mengarahkan system pembelajaran menjadi berpusat pada siswa dan peran guru hanya berfungsi sebagai fasilitator dan mengarahkan. Teknologi memiliki potensi dan peran untuk mempercepat proses tranformasi pendidikan. Melalui pemanfaatn alat-alat dan layanan teknologi secara holistic yang tidak hanya di dalam kelas atau dalam lingkup infrastruktur sekolah dan institusi pendidikan dapat memastikan perencanaan dan terfokus serta reformasi yang efisien dalam rangka mewujudkan perubahan efektif untuk meningkatkan mutu hasil capaian siswa. proses tranformasi pendidikan adalah sebuah siklus, proses yang terus berjalan dan munculnya revolusi digital 4.0 membantu mempercepat proses ini dan memastikan bahwa perubahan yang dibuat relevan dan efektif dalam mengatasi keterbatasan pembelajaran seperti masa pandemic covid-19 ini. Pergeseran pendidikan, paradigm pergeseran pendidikan kita tengah terjadi dengan adanya aliran informasi dan pengetahuan yang cepat dengan efisiensi penggunaan jasa teknologi informasi yang memungkinkan tembusnya batas-batas ruang dan waktu. Pergeseran pendidikan juga terjadi pada perubahan paradigm peran guru dalam proses pembelajaran, dimana pembelajaran tidak lagi berpusat pada guru tetapi lebih menekankan pada keaktifan siswa, kemudian dukungan teknologi juga memunculkan peran baru bagi guru sebagai fasilitator sebagaimana disebutkan sebelumnya. Sumber ilmu pengetahuan akan tersebar dimana-mana dan setiap orang akan dengan mudah dapat mengakses pengetahuan tanpa ada kesulitan.

Selaian itu pembelajaran dengan model perjenjangan yang terbatas menjadi pembelajaran seumur hidup bahwa kini belajar tidak hanya terbatas pada jenjang pendidikan dasar, menengah, dan tinggi. Namun belajar dapat dilakukan sepanjang hayat yang tidak terbatas pada tempat, usia, waktu, dan fasilitas. Konvertabilitas (pengkonversian) pendidikan, kualitas pendidik merupakan salah satu upaya untuk mengubah pendidikan kea rah yang lebih baik, kualitas pendidik dapat ditingkatkan dengan berbagai cara misalnya dengan memberikan pelatihan-peatihan untuk mengembangkan kemamuan yang sesuai dengan kualifikasi atau bidanngya atau dapat juga melakukan diklat, dan sebagainya. Pada masa pandemic ini bahwa kualitas guru harus ditingkatkan dalam hal penguasaan teknologi karena pembelajaran dilaksanakan daring atau online sehingga guru sebisa mungkin harus dapat mendesain model-model pembelajaran inovatif melalui e-learning. Fleksibilitas (Pelenturan) Pendidikan, pemerintah melalui kementerian pendidikan dan kebudayaan (kemendikbud) 
telah melakukan berbagai penyesuaian pembelajaran yang tidak membebani guru dan siswa, namun sarat nilai-nilai penguatan karakter seiring perkembangan covid-19. Penyesuaian tersebut tertuang dalam surat edaran yang telah dikelurakan mendikbud yang mendorong pada guru untuk tidak menyelesaikan semua materi dalam pembelajaran yang relevan seperti keterampilan hidup, kesehatan, dan empati. Selain itu kebijakan lain yang keluarkan adalah pembatalan ujian nasional (UN), penyesuaian ujian sekolah, implemntasi pembelajaran jarak jauh, dan pendekatan online untuk proses pendaftaran siswa sesuai surat edaran yang telah terbit. Kebijakan lain adalah penyesuaian pemanfaatan bantuan operasional sekolah (BOS) dan BOP yang fleksibel untuk memenuhi kebutuhan sekolah selama pandemic.

Saat ini banyak tersedia platform-platform yang memberikan free access untuk mendukung system pendidikan salah satunya yaitu melalui Edmodo yang merupakan aplikasi media social yang diperuntukan khusus untuk pendidikan yang menciptakan lingkungan belajar, dimana didalamnya tersedia fitur-fitur yang memadai seperti materi, layanan kuis, tugas, dan terdapat juga fasilitas pengontrol untuk orang tua, sehingga siswa dapat dikontrol oleh orang tua terkait dengan aktifitas belajar, tugas, dan lain sebagainya (Alwan, 2017). Selain itu pada masa pandemic covid-19 proses diskusi dan belajar banyak dilaksanakan menggunakan media Zoom, Google meet, WhatsApp, Google Classroom, dan lain sebagainya. Yang terpenting yaitu agar materi yang disajikan hendaknya dapat membantu siswa untuk belajar mandiri di rumah dengan menyediakan materi yang dapat didownload serta tugas-tugas yang tidak berat. Kemudian yang selanjutnya bahwa siswa sebagai desainer belajar, artinya bahwa siswa yang menjadi perancang belajarnya sendiri, sebagaimana dikatakan sebelumnya bahwa pembelajaran daring telah menyediakan berbagai sumber belajar yang dapat diakses dan dapat dibuka kapan saja dan dimana saja. Sehingga dengan tersedianya sumber belajar yang begitu mudah maka tergantung siswa bagaimana mengambil manfaat dari sumber yang ada. Kemudian sebagai desainer belajar bahwa siswa harus sedapat mungkin dalam pembelajaran online mengatur pola komunikasi dan diskusi dengan guru dan siswa agar terjalin komunikasi yang baik.

Adapun siasat menggerakan inovasi pembelajaran di masa disrupsi ini adalah yaitu dengan (1) Menyemaikan penelitian dan pengembangan sebagai bagian penting dari kegiatan pendidikan dan pembelajaran.(2) Memperkuat jaringan relasional antarunit kerja yang langsung berhubungan dengan inovasi pendidikan dengan mengurangi sekat ketertutupan, keterlepasan. (3) Menyebarluaskan dan mematrikan visi bersama untuk menjalankan programprogram dan kegiatan inovasi pendidikan.(4) Menumbuhkembangkan budaya inovasi dengan mengembangkan ekosistem organisasi yang menyadarkan semua 
akan pentingnya nilai lebih dari setiap kenerja dari waktu ke waktu. (5) Mentransformasi dan menstrukturisasi manajemen dan administrasi sedemikian rupa agar dapat mendukung bergeraknya inovasi pendidikan dan pembelajaran. (6) Menata ulang lingkungan atau ekosistem fisikal lembaga pendidikan. (7) Merancang dan mengembangkan apresiasi-apresiasi konstruktif terhadap inovasi yang sudah berhasil dilakukan oleh insan-insan pendidikan. (8) Melibatkan peserta didik, sebagai klien dan kolaborator, bahwa suara mereka didengar.

Sehingga pada akhirnya Djoko menyimpulkan bahwa inovasi pembelajaran masa pandemic covid-19 dapat dilaksanakan dengan pembelajaran digital, non digital, dan kombinasi. Pembelajaran digital dapat dilaksanakan dengan model pembelajaran E-Learning, Mobile Learning, Ubiquitous Learning, Gamfied Learning, dan Smart Mooc. Sedangkan pembelajaran dengan non digital dapat dilaksanakan dengan Belajar Berbasis Kehidupan, Belajar Responsif Budaya, Belajar Berbasis Pengalaman, Belajar Berbasis Kerja-Hidup Keseharian, dan Teaching Factory (Djoko, 2020). Sejalan dengan pendapat di atas Herman Fithra mengemukakan bahwa kebijakan belajar dari rumah mendorong siswa dan mahasiswa agar lebih inovatif dan kreatif dalam belajar (Student Centered Learning). Kreatif di tengah musibah prahara wabah covid-19 memang telah menjadi keprihatinan global dan mendunia.

Namun, sebagai pendidik, peserta didik, tak patut bagi kita untuk terpasung dalam kemurungan global terus menerus. Ada banyak inisiatif yang bisa dilakukan untuk bisa bersiasat di tengah kesulitan. Di dunia pendidikan, termasuk juga pendidikan tinggi, dapat memanfaatkan kemerdekaan berpikirnya untuk lepas dari masalah dan menatap masa depan dengan optimis dan penuh harapan. Salah satu yang dilakukan adalah 'me-lockdown' perkuliahan secara fisik yang sifatnya temporer serta memaksimalkan 'open up' kuliah model lain dengan memanfaatkan teknologi virtual dan digital. Revolusi industry 4.0 memungkinkan dalam melakukan inisiatif terbarukan untuk memaksimalkan fungsi komunikasi, transfer informasi, dan pengetahuan. Dunia boleh mewabah dan terimpit oleh pertumbuhan yang melambat, tetapi dunia pendidikan harus tetap berlari demi melanjutkan peradaban (Herman, 2020).

\subsection{Tantangan Pelaksanaan PBM masa Covid-19}

Sebagai upaya mencegah meluasnya penularan Covid-19 pada warga sekolah khususnya dan masyarakat luas pada umumnya, Kementerian Pendidikan dan Kebudayaan (kemendikbud) sebegaimana telah disebutkan pada bagian atas mengeluarkan beberapa surat edaran terkait pencegahan dan penanganan Covid-19. Pertama, Surat Edaran Nomor 2 Tahun 2020 tentang 
Pencegahan dan Penanganan Covid-19 di Lingkungan Kemendikbud. Kedua, Surat Edaran Nomor 3 Tahun 2020 tentang Pencegahan Covid-19 pada Satuan Pendidikan. Ketiga, Surat Edaran Nomor 4 Tahun 2020 tentang Pelaksanaan Kebijakan Pendidikan dalam Masa Darurat Penyebaran Coronavirus Disease (Covid-19) yang antara lain memuat arahan tentang proses belajar dari rumah.

Belajar dari rumah merupakan suatu kegiatan yang tidak biasa dilakukan dalam proses pembelajaran bagi siswa maupun mahasiswa. Proses belajar dari rumah dilaksanakan melalui pembelajaran jarak jauh atau PJJ. Fieka Nurul Arifa mengemukakan bahwa pembelajaran jarak jauh idealnya tetap dapat mengakomodasi kebutuhan belajar siswa untuk mengembangkan bakat dan minat sesuai dengan jenjang pendidikannya. Untuk mewujudkan hal tersebut maka diperlukan kesiapan pendidik, kurikulum yang sesuai, ketersediaan sumber belajar, serta dukungan piranti dan jaringan yang stabil sehingga komunikasi antar peserta didik dan pendidik dapat efektif. Lebih lanjut dikatakan bahwa PJJ saat ini belum dapat disebut ideal sebab masih terdapat berbagai hambatan yang dihadapi. Hambatan tersebut sekaligus menjadi tantangan dalam pelaksanaan PJJ mengingat pelaksanaan PJJ merupakan keharusan agar kegiatan pendidikan tetap dapat terselenggara di tengah darurat pandemic Covid-19 yang terjadi saat ini (Arifa, 2020).

Di sisi lain sejak 16 Maret sampai 9 April 2020 , Komisi Perlindungan Anak Indonesia (KPAI) menerima sekitar 213 pengaduan PJJ baik dari orang tua maupun siswa, pengaduan tersebut berkaitan dengan; Pertama penugasan yang terlalu berat dengan waktu yang singkat. Kedua, banyak tugas merangkum dan menyalin dari buku. Ketiga, jam belajar yang masih kaku. Keempat, keterbatasan kuota untuk mengikuti pembelajaran daring. Kelima, sebagian siswa tidak mempunyai gawai pribadi sehingga kesulitan dalam mengikuti ujian daring (Farisa, 2020).

Selanjutnya berdasarkan hasil survey Pusat Inovasi dan Kajian Akademik UGM terhadap 3.353 mahasiswa yang mengikuti pembelajaran daring dalam masa darurat Covid-19, sebanyak 66,9\% mahasiswa merasa memahami materi perkuliahan dengan baik, sedangkan sisanya mengaku kurang atau sangat kurang memahami dengan baik (Hastant0, 2020). Kurangnya pemahaman mahasiswa terhadap materi perkuliahan salah satunya disebabkan oleh kurang siapnya dosen dalam mengelola pembelajaran jarak jauh dengan baik. 


\section{Kesimpulan}

Pembelajaran masa era digital 4.0. pada masa Covid-19 mensyaratkan beberapa kriteria keterampilan yang harus dimiliki siswa dan mahasiswa untuk menyongsong masa depan yaitu fleksibilitas dan adaptabilitas pada proses pembelajaran covid-19, kemudian memiliki inisiatif siswa menjadi desainer dalam proses belajar. Kemudian learning dan innovation skills, communication and collaboration, dan creativity and innovation dan keterampilan teknolgi dan media informasi. Keterampilan ini merupakan yang dibutuhkan pada masa pandemic covid-19. Namun terkait dengan beberapa hal di atas terdapat beberapa hambatan dalam proses pembelajaran online masa covid-19 yaitu (1) penugasan yang terlalu berat dengan waktu yang singkat, (2) banyak tugas merangkum dan menyalin dari buku, (3) jam belajar masih kaku, (4) keterbatasan kuota, (5) sebagian siswa tidak mempunyai gawai pribadi sehingga kesulitan dalam memgikuti daring, (6) terbatasnya sarana infrastruktur karena tidak semua guru dan siswa memliki perangkat teknologi seperti smartphone dan laptop. Upaya pemerintah untuk mengatasi berbagai masalah tersebut yaitu diterbitkan surat edaran terkait dengan fleksibitas dalam penggunaan aggaran dana Bantuan Operasional Sekolah (BOS) untuk mendukung kegiatan pembelajaran online yaitu dapat digunakan untuk pembelian kuota. Saat ini banyak platform yang menyediakan aplikasi pembelajaran online yaitu Zoom, Google Classroom, Edmodo, WhtasApp, dan lain sebagainya. Dan pada akhirnya bahwa Dunia boleh mewabah dan terimpit oleh pertumbuhan yang melambat, tetapi dunia pendidikan harus tetap berlari demi melanjutkan peradaban anak bangsa.

\section{Referensi}

Ahmad, Intan. (2018). Proses Pembelajaran Digital dalam Era Revolusi Industri 4.0. Direktur Jenderal Pembelajaran dan Kemahasiswaan Kementerian Riset, Teknologi, dan Pendidkan Tinggi.

Alwan, M. (2017). Pengembangan model blended learning menggunakan aplikasi Edmodo untuk mata pelajaran geografi SMA. Jurnal Inovasi Teknologi Pendidikan, 4(1), 65-76. doi:https://doi.org/10.21831/jitp.v4i1.10505

Anggi, Afriansyah. (24 April 2020). Covid-19, Tranformasi pendidikan dan Berbagai Problemnya. Diakses tanggal 27 Mei 2020 https://kependudukan.lipi.go.id/id/berita/53-mencatatcovid19/838covid-19-transformasi-pendidikan-dan-berbagai-problemnya.

Arifa, Nurul F. (2020). Tantangan Pelaksanaan Kebijakan Belajar dari Rumah dalam Masa Darurat Covid-19. Pusat Penelitian Badan Keahlian DPR RI. Vol. XII. No. 7/1/Puslit/April/2020. Hal. 13-18. 
Conrad, Kerri \& Voris, Alvin C. (2002). Instrutional Design for Web-Based Training. USA: HRD Press.

DUGI Indonesia. (2019). Transformasi Perguruan Tinggi Era Pendidikan 4.0, mewujudkan "perguruan tinggi kelas dunia". Jakarta Selatan.

Farisa, Chusna, F. (13 April 2020). KPAI Terima 213 Pengaduan Pembelajaran Jarak Jauh, Mayoritas Keluhkan Beratnya Tugas dari Guru diakses 31 Mei 2020.

https://nasional.kompas.com/read/2020/04/13/15584711/kpai-terima213-pengaduan-pembelajaran-jarak-jauh-mayoritas-keluhkan?page $=1$

Fithra, Herman. (26 Maret 2020). Covid-19 dan Pembelajaran Daring. Diakses pada tanggal 31 Mei 2020.

https://mediaindonesia.com/read/detail/298964-covid-19-danpembelajaran-daring

Hastanto, Ikhwan. (24 Maret 2020). Warna-Warni Curhatan Guru dan Dosen yang Kini Terpaksa Mengajar Lewat Dunia Maya", 24 Maret 2020. diakses 31 Mei 2020.

https://www.vice.com/id id/article/pke8ak/sukaduka-belajar-jarakjauh-karenacorona-buat-guru-dan-dosen-diindonesia.

Lase, Delipiter. (2019). Penddikan di Era Revolusi Industri 4.0. Jurnal Sundermann. Vol. 1. No. 1. 1-17.

Muhammad, Hiru. (18 Maret 2020) .Sebanyak 850 Juta Siswa di Dunia Belajar di Rumah. Republika Online. Diakses tanggal 20 Mei 2020 https://republika.co.id/berita/q7e3gy380/sebanyak-850-juta-siswa-didunia-belajar-di-rumah.

Permendikbud (2014). Peraturan Menteri Pendidikan dan Kebudayaan No. 119 Tahun 2014 Tentang Penyelenggaraan Penddikan Jarak Jauh Jenjang Pendidikan Dasar dan Menengah.

Purwanto, Agus, et al. (2020). Studi Eksploratif Dampak Pandemi Covid-19 Terhadap Proses Pembelajaran Online di Sekolah Dasar. EdoPsycouns Journal. Volume 2 Nomor 1. 1-13

Putrawangsa, S. (2018). Desain Pembelajaran, Design Research sebagai Pendekatan Desain Pembelajaran. Mataram: CV. Reka Karya Amerta (Rekarta).

Sanur, Debora. (2020). Wacana Kebijakan Lockdown dalam menghadapi Covid-19 di Indonesia. Pusat Penelitian Badan Keahlian DPR RI. Vol.XII No. 6. 25-30.

Saryono, Djoko. (2020). Inovasi Pembelajaran Efektif di Tengah PandemiInfodemi Covid-19. Online International Webinar Pembelajaran Efektif di Masa Pandemi Covid-19, Inovasi Teknologi, Riset dan Pendidikan. Balikpapan, on may 19 2020. Makalah

Sugiyono. (2012). Metode Penelitian Kuantitatif Kualitatif dan $R \& D$. Bandung:Alfabeta.

Surat Edaran dari Menteri Pendidikan dan Kebudayaan Nomor: 36962/MPK.A/HK/2020 tertanggal 17 Maret 2020 tentang Pembelajaran secara Daring dan Bekerja dari Rumah dalam rangka Pencegahan Penyebaran Corona Virus Disease (COVID-19).

Surat Edaran Nomor 4 Tahun 2020 tentang Pelaksanaan Pendidikan Dalam 
Masa Darurat Coronavirus Disease (Covid-19).

Tambunan, Hamonangan. (2013). Pengembangan Pembelajaran Berbasis

Website Dalam Mata Kuliah Pengaturan Mesin Listrik. Cakrawala

Pendidikan. Th. XXXII. No. 1. 64-76

Permanent Delegation of The Republic Indonesia to UNESCO. (2019).

Sejarah. Diakses pada tanggal 27 Mei 2020.

https://kwriu.kemdikbud.go.id/tentang-kami/sejarah/5/

Yuliana. (2020). Corona virus diseases (Covid-19); Sebuah tinjauan literature.

WELLNESS AND HEALTHY MAGAZINE. Volume 2 Nomor 1 February 2020. 187-192. 